\title{
DAMPAK PANDEMI COVID-19 TERHADAP PENGELUARAN PANGAN RUMAH TANGGA MISKIN PERKOTAAN: STUDI KASUS KELUARAHAN CIROYOM, KECAMATAN ANDIR, KOTA BANDUNG
}

\section{IMPACT OF THE COVID-19 PANDEMIC ON FOOD EXPENDITURE OF URBAN POOR HOUSEHOOLDS: CASE STUDY KELURAHAN CIROYOM, KECAMATAN ANDIR, KOTA BANDUNG}

\author{
Elvira Aulia Hasanah*1, Mahra Arari Heryanto ${ }^{2}$, Hepi Hapsari ${ }^{2}$, Trisna Insan Noor ${ }^{2}$ \\ ${ }^{1}$ Program Studi Agribisnis Fakultas Pertanian Universitas Padjadjaran \\ Jl. Raya Bandung-Sumedang Km. 21 \\ ${ }^{2}$ Departemen Sosial Ekonomi Pertanian Fakultas Pertanian Universitas Padjadjaran \\ Jl. Raya Bandung-Sumedang Km. 21 \\ *E-mail: elvira17001@mail.unpad.ac.id \\ (Diterima 18-06-2021; Disetujui 16-07-2021)
}

\begin{abstract}
ABSTRAK
Dampak pandemi telah menurunkan besaran pengeluaran konsumsi pangan keluarga miskin akibat pendapatan menurun dan keterlambatan bansos pemerintah. Keluarga miskin terancam rawan pangan, karena akses pangannya menjadi terbatas di saat ketersediaan kasnya menurun. Penelitian ini bertujuan untuk menganalisis penyebab dan faktor keluarga miskin menjadi lebih rawan pangan serta mengetahui cara keluarga miskin mengelola pengeluaran pangannya di masa pandemi Covid19. Rancangan penelitian yang dilakukan menggunakan pendekatan system thinking. Analisis sistemnya menggunakan analisis konten berdasar pada system archetype. Tahap validasi struktur kesisteman menggunakan teknik triangulasi berdasar pada pengumpulan data dan pendekatan PRA melalui teknik bagan kecenderungan perubahan. Hasil penelitian menunjukkan bahwa kerawanan pangan keluarga miskin terjadi karena dampak pandemi yang menyebabkan akses terhadap pangan keluarga miskin semakin terbatas yang dicirikan oleh konsumsi pangan dari sisi kuantitas dan kualitas menurun. Faktor utama yang mempengaruhinya yaitu tingkat pendapatan. Strategi untuk mempertahankan kebutuhan konsumsi pangan keluarganya yaitu dengan mengajukan pinjaman dan beralih ke sumber pangan murah agar kualitas pangan tidak menurun sebanyak anggaran konsumsi pangan.
\end{abstract}

Kata kunci: pengeluaran pangan, ketahanan pangan, kemiskinan, system thinking, pandemi Covid19

\section{ABSTRACT}

The impact of the pandemic has reduced the amount of food consumption expenditure for poor families due to declining incomes and delays in government social protection. Poor families are threatened with food insecurity, because their access to food becomes limited when cash availability decreases. This study aims to analyze the causes and factors of poor families becoming more food insecure and to find out how poor families manage their food expenditure during the Covid-19 pandemic. The research design was carried out using a system thinking approach. The analysis of the system uses content analysis based on the system archetype. The validation stage of the system structure uses triangulation techniques based on data collection and the PRA approach through the trend change chart technique. The results show that food insecurity for poor families occurs due to the impact of the pandemic which causes access to food for poor families to be increasingly limited, which is characterized by decreased food consumption in terms of quantity and quality. The main factor that influences it is the level of income. The strategy to maintain their family's food consumption needs is to apply for a loan and switch to cheap food sources so that food quality does not decrease as much as the food consumption budget.

Keywords: food expenditure, food security, poverty, system thinking, Covid-19 pandemic 


\section{PENDAHULUAN}

Pandemi Covid-19 memberikan dampak pada perubahan perilaku dan aktivitas ekonomi masyarakat, sehingga menimbulkan adanya dorongan terhadap peningkatan angka kemiskinan (BPS, 2020). Pada pertengahan bulan Februari 2020, sebanyak 23\% rumah tangga di China yang telah keluar dari kemiskinan, kembali jatuh miskin saat pandemi Covid-19. Sebesar 7,1\% rumah tangga yang tidak pernah miskin pun menjadi miskin karena pandemi (Ren-Fu et al, 2020). Dalam skenario terburuk, tingkat kemiskinan di Indonesia naik sebesar $7,4 \%$ atau setara dengan 44,5 juta jiwa, dimana 19,7 juta jiwa di antaranya adalah kelompok penduduk miskin baru karena pandemi. Dalam skenario terbaik, jumlah penduduk yang jatuh miskin diprediksi meningkat sebesar 1,3 juta atau $0,48 \%$ (Suryahadi et al, 2020). Kenyataannya tingkat kemiskinan di Indonesia meningkat sebesar $0,60 \%$ menjadi $9,8 \%$ pada Maret 2020, dimana jumlah penduduk miskinnya mencapai 26,42 juta jiwa. Peningkatan penduduk yang jatuh miskin dalam periode ini sebanyak 1,6 juta, 1,3 juta jiwa adalah penduduk perkotaan (BPS, 2020).

Dampak terburuk akibat pandemi memukul lapisan rumah tangga yang sumber pendapatannya berasal dari pekerja sektor informal, dimana siklus pendapatannya harian dan tidak banyak memiliki tabungan, sehingga mereka sangat rentan kehilangan pendapatan (Maftuchan, 2020; Barany et al, 2020; BPS, 2020). Perlambatan ekonomi masyarakat menyebabkan rumah tangga pada lapisan ini kesulitan untuk memenuhi kebutuhan hidup, sehingga konsumsi rumah tangganya pun menurun, karena kemampuan daya beli yang menurun (Barany et al, 2020; TNP2K, 2020). Dampak terburuk pandemi dapat menyebabkan akses pangan keluarga miskin semakin terbatas yang dapat mengancam ketahanan pangan (TNP2K, 2020).

Semenjak dilakukannya PSBB di Jawa Barat pada 22 April 2021 untuk memutus penyebaran virus, ternyata menyebabkan penurunan pendapatan keluarga miskin di RT 04 RW 10 Kelurahan Ciroyom. Kelurahan Ciroyom merupakan salah satu kelurahan dengan persentase jumlah keluarga miskin $(9,1 \%)$ di atas rata-rata Kota Bandung (10,1\%) pada tahun $2019^{1}$. Berdasarkan fenomena tersebut, penelitian ini bertujuan untuk menganalisis penyebab dan faktor keluarga miskin menjadi lebih

${ }^{1}$ Diolah dari open data Kota Bandung tahun 2020 
rawan pangan sebagai dampak dari pandemi Covid-19. Terkait dengan akses pangan yang terganggu akibat pandemi, diharapkan pemerintah mampu memastikan semua keluarga miskin untuk mendapat bantuan sosial agar tidak berdampak besar terhadap ketahanan pangan dan gizi rumah tangga (Arif et al, 2020).

\section{METODE PENELITIAN}

Pendekatan system thinking digunakan untuk mendeskripsikan pengelolaan pengeluaran pangan keluarga miskin. Pendekatan berpikir sistem merupakan desain penelitian metode kualitatif yang sejalan dengan kerangka pikir induktif (Saeed, 1988). Makalah ini menggunakan metode kualitatif yang bertujuan untuk memahami gejala dari masalah dan mengeksplorasi fakta dan fenomena sosial yang terjadi di lapangan (Cooper \& Schindler, 2014).

Pendekatan system thinking mampu mempelajari perubahan sesuatu terhadap waktu, mengetahui sesuatu yang tidak terlihat, membaca kemungkinan peristiwa di kemudian hari, bahkan mengulang peristiwa yang sudah lampau (Richmond, 1993; Haraldsson, 2004). Cara berpikir sistem merajuk pada four level of thinking yang dimulai dari events, pattern of behavior, systemic structures dan mental models (Kirkwood, 1998; Morrison, 2001). Berdasarkan tingkatan tersebut, analisis berpikir sistem dimulai dari; (1) identifikasi masalah, (2) konseptualisasi system, dan (3) formulasi model. Jenis data yang digunakan terdiri atas numerical data base, written data base dan mental data base (Luna-Reyes \& Andersen, 2003). Data mental berisi informasi atau mind set dari informan. Data tertulis mencakup konsep dan abstraksi, biasanya merupakan literatur, sedangkan data numerik bersifat historis yang memuat data dalam suatu rentang waktu tertentu (Heryanto \& Suryatmana, 2020). Teknik pengumpulan data pada tahapan konseptualisasi sistem menggunakan in-depth interview dan observation, sedangkan untuk merancang formulasi modelnya menggunakan content analysis (Luna-Reyes \& Andersen, 2003).

Analisis konten yang digunakan yaitu system archetype yang dapat menghasilkan reference modes atau mengenali pola tingkah laku sistem. Archetype dapat melihat prospek yang akan datang melalui perencanaan dan melukiskan diagram sebab akibat/Causal Loop Diagram (CLD) (Supyandi et al, 2014). Beberapa bagian dalam CLD yaitu 
variabel, panah dan polaritas. Panah mengartikan hubungan kausalitas, sedangkan polaritas ditandakan dengan simbol positif $(+)$ atau negatif $(-)$ yang ditempatkan di sebelah panah. Simbol positif berarti mewakili adanya hubungan searah, sedangkan negatif menandakan adanya hubungan terbalik. Variabelvariabel dalam sistem membentuk hubungan circular relations/feedback loops, dimana terdapat feedback loops positif dengan tanda (R) (Reinforcing) dan feedback loops negatif yang ditandai (B) (Balancing). Aspek penting untuk menentukan dinamika dalam suatu sistem terdiri atas feedback loops, delays, stock and flow dan non-linearity (Forrester, 1961).

Tahap pengujian struktur yang digunakan untuk memvalidasi model yaitu menggunakan teknik triangulasi yang dilakukan bersamaan pada saat proses pengumpulan data. Selain itu, digunakan juga Participatory Rural Appraisal (PRA) dengan menggunakan teknik bagan kecenderungan perubahan untuk menganalisis kecenderungan perubahan pada perilaku yang sudah tergambarkan.

Penelitian yang dilakukan merupakan sebuah studi kasus bersifat khusus, mendeskripsikan hasil kajian secara rinci dan mendalam (Cooper \& Schindler, 2014). Lokasi studi kasus berada di RT 04, RW 10, Kelurahan Ciroyom, Kecamatan Andir, Kota Bandung. Keunikan dari lokasi tersebut adalah sebagian besar dari masyarakatnya yang berprofesi di sektor informal mulai dari buruh, pedagang, wirausaha skala mikro, menengah dan kecil. Berdasarkan observasi lapangan, diperoleh fenomena banyak masyarakat yang mengeluhkan ketidaknyamanan seperti pemberhentian sementara, pemotongan gaji, tidak mendapat THR dan insentif cadangan selama PSBB, pembeli menurun, omset yang menurun serta kerugian lainnya.

\section{HASIL DAN PEMBAHASAN}

1. Kondisi Ekonomi Keluarga Miskin

\section{a) Pendapatan}

Pendapatan keluarga miskin yang berada di RT 04 RW 10 Kelurahan Ciroyom mulai menurun pada bulan Maret saat kasus positif Covid-19 pertama kali terjadi di Indonesia. Pendapatan menurun drastis ketika kebijakan social distancing (PSBB) mulai diterapkan pada pertengahan April 2020 di Kota Bandung selama dua pekan. Rata-rata pendapatan mereka pada sebelum pandemi Rp2.650.000, ketika 
pandemi menjadi Rp2.009.091, dengan rata-rata penurunanya sebesar $24,19 \%$.

\section{b) Pengeluaran Konsumsi}

Merespon penurunan tingkat pendapatan, rata-rata pengeluaran konsumsi menurun sebesar 23,99\%, sebesar 25,43\% merupakan rata-rata penurunan anggaran konsumsi pangan.
Rata-rata proporsi pengeluaran pangan selalu lebih besar dari non-pangannya yaitu 70\% (Tabel 1). Dalam penelitian Harianto dan Susila (2009) juga menyebutkan bahwa rumah tangga berpendapatan rendah mengalokasikan pengeluaran pangannya lebih dari $70 \%$.

Tabel 1. Rata-rata Besaran dan Persentase Pengeluaran Keluarga Miskin Sebelum dan Saat Pandemi

\begin{tabular}{cccccc}
\hline \multirow{2}{*}{ Jenis Pengeluaran } & \multicolumn{2}{c}{ Sebelum Pandemi } & \multicolumn{2}{c}{ Saat Pandemi } \\
\cline { 2 - 5 } & Jml (Rp/Bln) & Proporsi (\%) & Jml (Rp/Bln) & Proporsi (\%) \\
\hline \multirow{2}{*}{ Konsumsi } & Pangan & $1,623,181.82$ & $70.60 \%$ & $1,210,363.64$ & $69.80 \%$ \\
& Non Pangan & $676,090.91$ & $29.40 \%$ & $523,636.36$ & $30.20 \%$ \\
\hline \multicolumn{2}{c}{ Total Konsumsi } & $\mathbf{2 , 2 9 9 , 2 7 2 . 7 3}$ & $\mathbf{1 0 0 \%}$ & $\mathbf{1 , 7 3 4 , 0 0 0 . 0 0}$ & $\mathbf{1 0 0 \%}$ \\
\hline
\end{tabular}

Sumber: Data Primer (2020)

\section{Keadaan Akses Pangan Keluarga} Miskin

\section{a) Konsumsi Pangan}

Penurunan konsumsi pangan disajikan pada Tabel 2, dicirikan dengan TKE sebelum pandemi $64,30 \%$ menjadi $57,66 \%$ saat pandemi. Rata-rata penurunan TKG untuk sumber energi dan protein menurun sebesar $10,33 \%$ dan 17\%. Mereka lebih banyak menurunkan kualitas gizi sumber protein daripada sumber karbohidratnya. Rata-rata penurunan tingkat kecukupan gizinya hanya mencapai $13,67 \%$.

Tabel 2. Rata-rata Konsumsi Energi dan Protein serta Tingkat Kecukupan Gizi Keluarga Miskin

\begin{tabular}{lcccc}
\hline \multirow{2}{*}{ Keterangan } & \multicolumn{2}{c}{ Sebelum Pandemi Covid-19 } & \multicolumn{2}{c}{ Saat Pandemi Covid-19 } \\
\cline { 2 - 5 } & \multicolumn{2}{c}{ Per Individu Per Hari } & \multicolumn{2}{c}{ Per Individu Per Hari } \\
& Energi $(\mathrm{kkal} / \mathrm{hr})$ & Protein $(\mathrm{gr} / \mathrm{hr})$ & Energi $(\mathrm{kkal} / \mathrm{hr})$ & Protein $(\mathrm{gr} / \mathrm{hr})$ \\
\hline Konsumsi & 1261.41 & 53.98 & 1131.09 & 44.75 \\
AKG yang dianjurkan & 1961.70 & 51.14 & 1961.70 & 51.14 \\
TKG (\%) & 64.30 & 105.55 & 57.66 & 87.50 \\
\hline
\end{tabular}

Sumber: Data Primer (2020)

\section{b) Ketahanan Pangan}

Tingkat ketahanan pangan keluarga miskin diukur dengan menggunakan klasifikasi silang dua indikator ketahanan dilihat dari sisi proporsi pengeluaran pangan dan kecukupan konsumsi energi (kkal) rumah tangganya. Keluarga miskin yang rawan pangan pada sebelum dan saat pandemi mencapai 66,67\%. Mereka menghabiskan rata-rata proporsi pengeluaran pangannya sebesar $70 \%$. Penelitian Arif et al (2020) juga menyatakan bahwa rumah tangga perkotaan yang rawan pangan 
menghabiskan rata-rata pengeluaran pangannya sebesar $68 \%$. Sedangkan ratarata tingkat kecukupan energi pada sebelum dan saat pandemi hanya mampu memenuhi kecukupan energi sebesar $55,88 \%$. Tingkat kecukupan energinya telah menurun $11 \%$ di saat pandemi, semula 59,12\% menjadi 52,64\%.

\section{Bantuan Sosial Pemerintah}

Penyaluran bansos mengalami keterlambatan selama tiga bulan, mulai dari akhir bulan Februari hingga akhir bulan Mei. Adanya delay pada distribusi bansos menyebabkan ketidakmampuan mereka untuk menutupi pengeluaran pangan keluarganya. Pada situasi inilah sebagian keluarga miskin mengajukan pinjaman uang kepada lembaga koperasi UMKM/PNM. Oleh sebab itu, terdapat beban membayar angsuran yang muncul di saat pandemi, dimana rata-ratanya sebesar Rp630.000/bln.

Pemerintah membuat program bansos non-regular dalam bentuk paket sembako dan tunai dengan tujuan agar keluarga miskin tidak sampai kerawanan pangan akibat melemahnya daya beli. Beberapa jenis bansos yang diterima oleh keluarga miskin disajikan pada Tabel 3 beserta rincian besaran nilai manfaatnya.

Tabel 3. Jenis-jenis dan Besaran Nilai Manfaat Bantuan Sosial yang Diterima Keluarga Miskin di RT 04 RW 10 Kelurahan Ciroyom

\begin{tabular}{|c|c|c|c|c|}
\hline $\begin{array}{c}\text { Program } \\
\text { Perlindungan Sosial }\end{array}$ & Jenis Bansos & Besaran Nilai & Ianfaat & Satuan \\
\hline \multirow{6}{*}{ Regular (R) } & \multirow{4}{*}{ PIP } & SD & 450,000 & \multirow{6}{*}{ Rp/Tahun } \\
\hline & & SMP & 750,000 & \\
\hline & & SMA/SMK & $1,000,000$ & \\
\hline & & Program 4 Thn & $1,000,000$ & \\
\hline & \multirow{2}{*}{ BPNT } & Sebelum Pandemi & 110,000 & \\
\hline & & Saat Pandemi & 200,000 & \\
\hline \multirow{7}{*}{ Non-Regular (NR) } & BST & & 300,000 & Rp/Bulan \\
\hline & \multirow{4}{*}{$\begin{array}{l}\text { BanGub } \\
\text { (Bantuan Prov. } \\
\text { Jawa Barat) }\end{array}$} & Tahap I & 550,000 & Rp/Bulan, pada bulan Mei \\
\hline & & Tahap II & 550,000 & Rp/Bulan, pada bulan Juli \\
\hline & & Tahap III & 350,000 & Rp/Bulan, pada bulan Oktober \\
\hline & & Tahap IV & 100,000 & Rp/Bulan, pada bulan Juli \\
\hline & $\begin{array}{l}\text { Subsidi Upah } \\
\text { Pekerja }\end{array}$ & & $2,400,000$ & Rp/sekali pemberian \\
\hline & Hibah UMKM & & $2,400,000$ & Rp/sekali pemberian \\
\hline
\end{tabular}

Sumber: Diolah Peneliti dari berbagai sumber

Manfaat bansos dapat dikatakan optimal jika proses penyalurannya sudah sesuai dengan tujuan yang ditetapkan. Jika dilihat dari tepat jumlah, ternyata besaran nominal yang diberikan belum cukup memenuhi sebagian besar pengeluaran pangan keluarga miskin, bahkan proporsinya hanya menutup sebagian kecil dari total pengeluaran rumah tangga mereka.

Ketidaktepatan mekanisme distribusi terjadi pada bansos pangan. 
Menurut TNP2K (2020), pelaksanaan BPNT tahun 2019 dan Program Sembako tahun 2020 melenceng dengan anjuran pemerintah yang menginstruksikan bahwa setiap KPM dapat membelanjakan bahan pangan sesuai dengan kebutuhannya. Dikutip dalam TNP2K menurut Susenas (2019), sebesar 14\% KPM dapat menentukan pangannya berdasarkan keinginan sendiri, sedangkan 86\% lainnya memperoleh bahan pangan paketan yang telah diatur oleh agen ewarong. Hal ini ternyata dirasakan juga oleh mereka, dimana bahan pangan yang diterima setiap penukaran KKS per bulannya sudah berupa paketan. Bahan pangan yang dipaketkan tersebut terdiri atas beras kualitas sedang $10 \mathrm{~kg}$, daging ayam $1 \mathrm{~kg}$, telur $500 \mathrm{gr}$, sayur-mayur \pm 1 $\mathrm{kg}$, dan buah-buahan \pm 500 gr.

\section{Pola Perubahan Pengeluaran Pangan Keluarga Miskin}

Perubahan pendapatan yang menurun karena pandemi menurunkan anggaran konsumsi pangan. Strategi yang dilakukan yaitu dengan melakukan pinjaman, dimana pinjaman tersebut menambah ketersediaan kas rumah tangga, tetapi menambah beban membayar angsuran. Pemerintah memberikan bansos untuk meringankan beban pengeluaran pangan keluarga miskin agar tidak memicu kerawanan pangan yang parah, namun besarannya belum mampu menutupi sebagian besar pengeluaran pangan keluarga miskin. Akhirnya keluarga miskin memilih alternatif lain yaitu dengan beralih ke sumber pangan murah demi menjaga ketahanan pangan keluarganya.

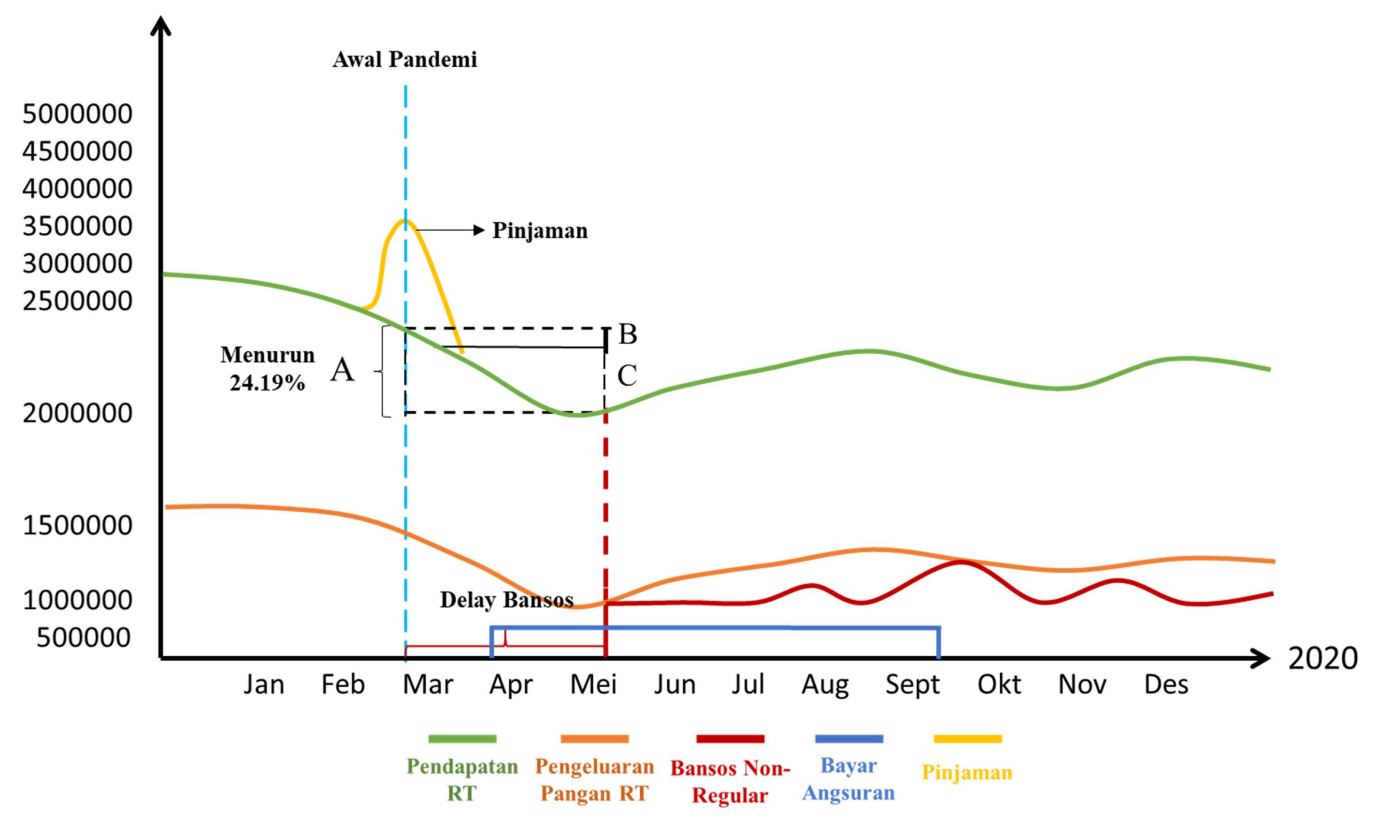

Gambar 1. Pola Perubahan Alokasi Pengeluaran Pangan Keluarga Miskin Saat Pandemi 
3. Struktur Sistem Kerawanan Pangan

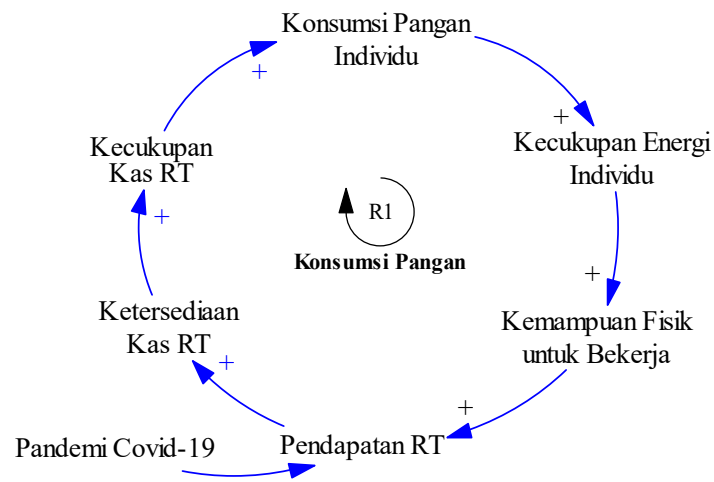

Gambar 2. Struktur Feedback Loops Konsumsi Pangan (R1)

Tingkat pendapatan merupakan faktor kunci untuk memperoleh pangan dilihat dari kemampuan daya belinya, kuantitas dan kualitas pangannya (BKP, 2019). Pendapatan yang menurun sebesar $24,19 \%$ akibat pandemi menyebabkan ketersediaan kas rumah tangga menjadi sedikit. Di masa pandemi yang sulit, ditambah dengan ketersediaan kas yang sedikit, menyebabkan keluarga terdampak terancam kehilangan daya belinya akibat ketidakcukupan kas untuk membeli sejumlah bahan pangan untuk konsumsi sehari-hari keluarganya. Dengan demikian, kebutuhan konsumsi pangan keluarga miskin semakin menjauhi tingkat kecukupan energi, sehingga keluarga miskin terancam rawan pangan.

\section{Faktor yang Mempengaruhi Kerawanan Pangan}

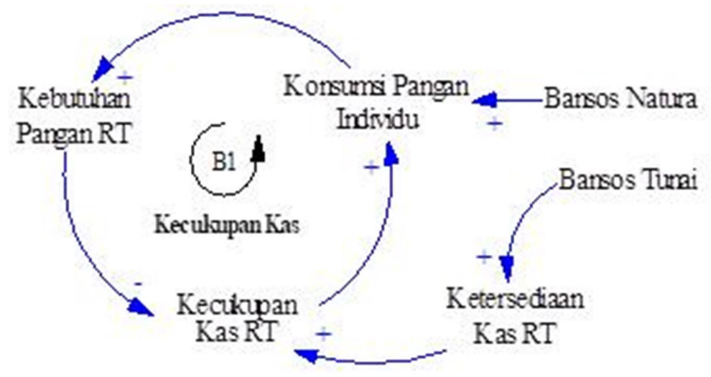

Gambar 3. Struktur Feedback Loops

Kecukupan Kas Rumah Tangga (B1)

Penyaluran bansos regular dan nonregular diberikan dalam dua bentuk, yaitu natura berupa paket sembako dan bentuk tunai (Maftuchan, 2020). Manfaat bansos dicerminkan dalam struktur CLD pada Gambar 3, dimana bansos tunai akan menambah ketersediaan kas rumah tangga dan bansos natura akan memperbaiki kualitas pangan keluarga terdampak.

Tingkat kecukupan kas untuk membeli sejumlah bahan pangan diperoleh dari perbandingan antara konsumsi pangan per individu dalam rumah tangga dengan kebutuhan pangan rumah tangganya. Semakin banyak kebutuhan pangan rumah tangga, maka kecukupan kas untuk memenuhinya semakin sedikit. Hal tersebut terjadi pada $\begin{array}{llllll}\text { keluarga miskin di } & \text { RT } & 04 & \text { RW } & 10\end{array}$ Kelurahan Ciroyom, dimana hubungan ini dalam struktur dicirikan dengan 
feedback loops bertanda (B1) pada

Gambar 3.

Rata-rata kebutuhan pangan keluarga miskin sebesar 1961,70 kkal/individu/hr. Namun, mereka hanya mampu memenuhi kebutuhan konsumsi pangan keluarganya sebesar 1261,41 $\mathrm{kkal} / \mathrm{individu} / \mathrm{hr}$ (sebelum pandemi) dan
1131,09 kkal/individu/hr (saat pandemi).

Hal ini menunjukkan bahwa mereka belum mampu mencukupi kebutuhan pangan yang dianjurkan baik sebelum dan saat pandemi akibat ketersediaan kasnya yang tidak cukup untuk memperoleh sejumlah bahan pangan yang dibutuhkan.

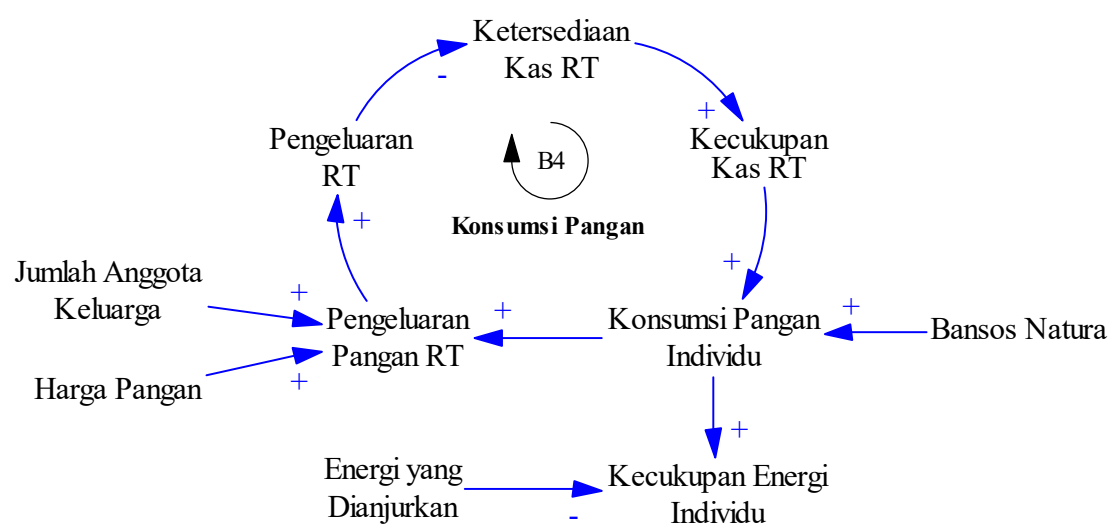

Gambar 4. Struktur Feedback Loops Konsumsi Pangan (B4)

Hubungan ketersediaan pangan dan akses pangan dalam ketahanan pangan rumah tangga dicerminkan melalui konsumsi pangan rumah tangga itu sendiri dalam memperoleh pangan. Hubungan ini menghasilkan feedback loops (B4), dimana pengeluaran pangan rumah tangga dipengaruhi oleh jumlah anggota keluarga dan harga pangan. Semakin banyak individu dalam keluarga, maka semakin banyak konsumsi pangan keluarganya. Jika harga pangan tidak dipilah, maka pengeluaran pangan semakin tinggi, akhirnya menambah pengeluaran rumah tangga dan menguras lebih banyak ketersediaan kas.

Harga pangan yang tinggi dapat menyebabkan semakin besarnya pengeluaran pangan (BKP, 2019). Jika harga suatu komoditas pangan tinggi, tetapi pendapatan rumah tangga rendah atau tidak cukup, maka kebutuhan gizinya pun terancam (Rachman dan Ariani, 2002). Tidak heran tingkat kecukupan energi keluarga miskin cenderung rendah dan mengalami penurunan saat pandemi.

Penurunan konsumsi pangan keluarga miskin ditunjukkan melalui TKG yang telah menurun sebesar $13,67 \%$ 
akibat adanya penurunan pengeluaran konsumsi pangan sebesar $25,43 \%$. Hal ini menunjukkan bahwa akses pangan keluarga miskin semakin terbatas. Keadaan ini dicerminkan melalui ketidakcukupan keluarga miskin dalam memenuhi kebutuhan pangan keluarganya. Ketidakcukupan untuk memperoleh pangan dapat memicu kerawanan pangan rumah tangga (BKP, 2019).

\section{Strategi Ketahanan Pangan}

Ketidakcukupan kas untuk memenuhi konsumsi pangan, menyebabkan sebagian keluarga terdampak mengajukan pinjaman di awal pandemi, di saat ketersediaan kas rumah tangganya sama dengan pengeluaran pangannya. Pinjaman menimbulkan beban membayar angsuran. Angsuran akan semakin besar, jika suku bunga pinjaman tinggi dan waktu cicilan yang lama. Pinjaman dan beban membayar angsuran membentuk feedback loops negatif (B3). Pembayaran beban angsuran akan mengurangi kewajiban mereka untuk membayar hutang. Tetapi di sisi lain, beban tersebut telah menambah pengeluaran rumah tangga di luar konsumsi pangan dan non-pangan.

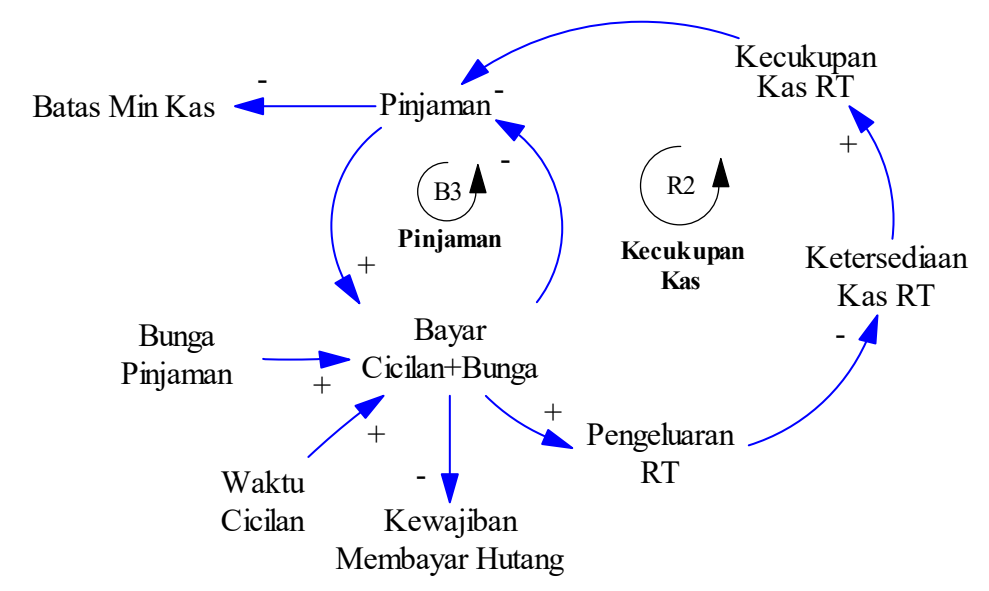

Gambar 5. Struktur Feedback Loops Pinjaman Rumah Tangga (B3)

Dalam jangka panjang, pinjaman bukanlah pilihan strategi yang baik, karena mengurangi ketersediaan kas, akibat beban membayar angsuran, kemudian menyebabkan ketidakcukupan kas rumah tangga (R2). Oleh sebab itu, di saat ketersediaan kas belum cukup banyak menutupi kebutuhan konsumsi pangan keluarganya, mereka mencoba memilih alternatif lain dengan cara berhemat melalui sumber pangan murah. 


\section{KESIMPULAN DAN SARAN}

\section{Kesimpulan}

1. Kerawanan pangan terjadi karena akses pangan keluarga miskin semakin terbatas akibat pandemi yang telah menurunkan pendapatan rumah tangga. Keterbatasan akses terhadap pangan dicirikan melalui ketidakcukupan kas rumah tangga untuk memperoleh pangan.

2. Tingkat pendapatan merupakan faktor utama selain harga pangan dan jumlah anggota keluarga yang menentukan ketahanan pangan di tingkat rumah tangga, karena berkaitan dengan cara perolehan pangan yang dapat mencerminkan kemampuan daya beli untuk memperoleh pangan dan konsumsi pangan keluaranya baik dari sisi kuantitas maupun kualitas pangannya.

3. Strategi yang dilakukan mereka untuk mempertahankan kebutuhan konsumsi pangan keluarganya dalam menghadapi kesulitan di masa pandemi, yaitu dengan mengajukan pinjaman dan beralih ke sumber pangan murah.

\section{Saran}

1. Pemerintah sebaiknya lebih siaga mempersiapkan program bansos ketika suatu pandemi terjadi dengan memperhatikan ketepatan waktu, jumlah dan mekanisme distribusinya. Pemantauan dan evaluasi program bansos sangat diperlukan agar tujuan program bansos tidak bias, sehingga hak-hak keluarga penerima manfaat tidak tersingkirkan. Diharapkan akses pangan dapat tercipta melalui program bansos pangan untuk menjaga ketahanan pangan keluarga miskin.

2. Rumah tangga berpendapatan rendah tidak seharusnya mengajukan pinjaman sebagai cara untuk bertahan hidup, karena tidak memberikan manfaat jangka panjang, justru hanya menambah beban pengeluaran rumah tangga.

\section{DAFTAR PUSTAKA}

Arif, S., Isdijoso, W., Fatah, A.R.F., \& Tamyis, A.R. (2020). Tinjauan Strategis Ketahanan Pangan dan Gizi Indonesia: Informasi Terkini 2019-2020. Jakarta: Smeru Reseacrh Intitute.

Barany, L.J., Simanjuntak, I., Widia, D.A., \& Damuri, Y.R. (2020). Bantuan Sosial Ekonomi di Tengah Pandemi Covid-19: Sudahkan Menjaring Sesuai Sasaran? CSIS Commentaries ECON-002-ID.

BKP, Kementan. (2019). Analisis Ketersediaan pangan: Neraca Bahan Makanan Indonesia 20172019. Jakarta: Kementan dan BPS. 
BPS. (2020). Laporan Bulanan Data Sosial Ekonomi. Jakarta: BPS.

Chambers, R. (1994). The Origins and Practice of Participatory Rural Appraisal. World Development, 22(7): 953-969.

Cooper, D.R. \& Schindler, P.S. (2014). Business Reaseacrh Methods, Twelfth Editition. New York: McGraw-Hill/Irwin.

Forrester, J.W. (1961). Industrial Dynamics. Portland, OR: Productivity Press.

Haraldsson, H.V. (2004). Report in Ecology and Environmental Engineering: Introduction to System Thinking and Causal Loop Diagrams. Sweden: KFS AB, Department of Chemical Engineering, Institute of Technology, Lund University.

Harianto \& Susila, D.A.B. (2009). Permintaan Beras Rumah Tangga Petani. Jurnal Agribisnis dan Ekonomi Pertanian, 3(2): 90-103.

Heryanto, M.A. \& Suryatmana, E.R. (2020). Dinamika Agroindustri Gula Indonesia: Tinjauan Analisis Sistem. Jurnal Agribisnis dan Sosial Ekonomi Pertanian UNPAD, 5(2): 194-210.

Kirkwood, C.W. (1998). System Dynamics Methods: A Quick Introduction. College of Business, Arizona State University, 126.

Luna-Reyes, L.F. \& Andersen, D.L. (2003). Collecting and Analyzing Qualitative Data for System Dynamics: Methods and Models. Wiley InterScinece (Winter), System Dynamics Review, 19(4): 271-296.

Maftuchan, A. (2020). Program Tunai di Era Covid-19: Bantuan Tunnai Korona atau Jaminan Penghasilan Semesta. PRAKARSA, Policy Brief.
Morrison, Terrence. 2001. Actionable Learning: A Handbook for Capacity Building Through Case Based Learning. Japan: Asian Development Bank Institute

Rachman, H.P.S. \& Ariani, M. (2002). Ketahanan Pangan: Konsep, Pengukuran dan Strategi. Jurnal Forum Penelitian Agro Ekonomi (FAE), 20(1): 12-24.

Richmond, B. (1993). Systems Thinking: Critical Thinking Skills for the 1990s and Beyond. System Dynamics Review, 9(2): 113-133.

Ren-Fu, L., Cheng-fang, L., Jing-jing G., Tian-yi, W., Hua-yong, Z., Pengfei, Shi \& Ji-kun, H. (2020). Impacts of The Covid-19 Pandemic on Rural Poverty and Policy Responses in China. Journal of Integrative Agriculture, 19(12): 2946-2964.

Saeed, Khalid. 1988. "System Dynamics Modelling for the Design of Change." In Proc. Conf. 1988 International System Dynamics Society, La Jolla, Calif, p. 311-323.

Supyandi, D., Sukayat, Y. \& Heryanto, M.A. (2014). Beras Organik: Upaya Meningkatkan Daya Saing Produk Pertanian (Studi Kasus di Kab. Bandung Prop. Jabar). Journal \& Proceeding FEB Unsoed, 4(1): 190-210.

Suryahadi, A., Al Izzati, R \& Suryadarma D. (2020). Estimating the Impact of Covid-19 on Poverty in Indonesia. Bulletin of Indonesia Economic Studies, 56(2): 175-192.

TNP2K. (2020). Ringkasan Kebijakan: Memaksimalkan Peran Program Sembako pada Masa Pandemi Covid-19. Jakarta: Australian Government, Sekretariat TNP2K. 